\title{
Connecting HRM and Change Management: The Importance of Proactivity and Vitality
}

Accepted article for the Journal of Organizational Change Management

\author{
Dr. Lars Tummers*, Dr. Peter Kruyen**, Drs. Dominique Vijverberg MBA*** and \\ Tessa Voesenek MSc****1
}

To be cited as:

Tummers, L.G., Kruyen, P., Vijverberg, D., \& Voesenek, T. (2015). Connecting HRM and Change Management: The Importance of Proactivity and Vitality. Journal of Organizational Change Management, 28(4), 627 - 640. (SSCI-ranked).

\footnotetext{
* Erasmus University Rotterdam and University of California, Berkeley, Tummers@fsw.eur.nl, ** Radboud University Nijmegen, *** Stichting IZZ, **** Erasmus University Rotterdam
}

\footnotetext{
${ }^{1}$ Acknowledgements: The data were collected as part of IZZ VitaliteitvoordeZorg, which is funded by Stichting IZZ. Stichting IZZ is a nonprofit collective of employers and employees in healthcare. The authors did not receive any funding for writing this article.

The authors would like to thank Marcel Lankhaar (PwC), Eline Nap (PwC), Annelies Versteegden (former PwC) and Anouk ten Arve (Stichting IZZ) for their contributions in developing this study. Furthermore, the authors would like to thank the two anonymous reviewers for their constructive suggestions on previous versions of this article.
} 


\title{
CONNECTING HRM AND CHANGE MANAGEMENT
}

\begin{abstract}
Purpose. Organizations are continuously under pressure to adapt to changing circumstances. Job proactivity and vitality are important in changing environments. For instance, vital employees can better deal with change because they possess more energy. However, it is still unclear how organizations can stimulate proactivity and vitality. This study connects HRM and change management by analyzing how HRM practices can stimulate job proactivity and vitality.
\end{abstract}

Design. We used survey data collected in three large public healthcare organizations in the Netherlands $(n=1,507)$ to investigate the effects of five important HRM practices on proactivity and vitality. Analyses were performed using Structural Equation Modeling.

Findings. Results suggest that three HRM practices are particularly effective for improving proactivity and vitality: 1) high autonomy, 2) high participation in decision-making, and 3) high quality teamwork. Based on these results, we discuss the possibilities of using HRM to improve employees' abilities to deal with organizational change.

Originality. This study is one of the first to empirically connect HRM to change management. Furthermore, it uses new concepts derived from positive psychology (job proactivity and vitality) to show how HRM can be beneficial for organizational change.

Keywords: Human Resources Management, HRM, Change Management, Job Proactivity, Vitality, High Performance Work Practices, Positive Psychology 


\section{CONNECTING HRM AND CHANGE MANAGEMENT}

\section{Introduction}

Organizations are continuously under pressure to adapt to changing circumstances, such as changing client wishes, new policy developments, and the introduction of social media (Josserand et al., 2006). Swift adaptation to changing conditions has always been considered crucial for the survival of private-sector organizations (Tushman and O'Reilly, 2013). However, nowadays a critical public opinion and shrinking budgets pose threats to the survival of public organizations as well, which requires them to change rapidly and profoundly (Kuipers et al., 2014; Van der Voet et al, 2013).

Even if employees are generally willing to change, the change process can be a stressful burden (Vakola and Nikolaou, 2005). Employees have to change their daily routines, acquire new knowledge and face peaks in workload. Such a situation can lead to resistance to further changes, burnout, and staff turn-over (Rush et al., 1995). To cope successfully with organizational change, positive psychology scholars argue that job proactivity and vitality are of particular importance (e.g., Ghitulescu, 2013; Shirom, 2011). Proactive employees anticipate possible future events and take initiative (Grant and Ashford, 2008). High levels of proactivity are beneficial when working in new, uncertain, circumstances such as when confronted with organizational change (Hornung and Rousseau, 2007). Vitality is defined as one's conscious experience of possessing energy and liveliness (Kark and Carmeli, 2009). Vital employee can potentially better deal with change because they possess more energy (Carmeli and Spreitzer, 2009).

Since employee proactivity and vitality may be such important assets for organizational change, the question arises whether it is possible to enhance their levels. Several authors (Combs et al., 2006; Wright et al., 2005) showed that particular human resource management practices, including training, feedback, and teamwork are strongly related to both individual and organizational outcomes. Such HRM practices are often labeled 


\section{CONNECTING HRM AND CHANGE MANAGEMENT}

"High Performance Work Practices" (HPWPs) (Boselie et al., 2005). We expect that organizations can enhance proactivity and vitality - and thus facilitating organizational changes - using such High Performance Work Practices. The goal of this article is therefore to analyze the influence of five of the most important HPWPs on employee pro-activity and vitality.

This study is innovative in two ways. First, we focus on the effects of HPWPs on active job outcomes, thereby empirically connecting HRM with change management (see Doorewaard and Benschop, 2002 for a conceptual contribution). To date, most HRM research has studied the effects of HPWPs on passive job outcomes, such as satisfaction and organizational commitment (e.g., Bauer, 2004). There is a dearth on studies connecting HPWPs with active employee outcomes such as vitality and pro-activity (Kark and Carmeli, 2009)

The second innovation is that we analyze HPWPs as perceived by the employee. Scholars have acknowledged that more research is needed concerning perceived HRM practices as in contrast to intended or actual HRM policies (Macky and Boxall, 2007). As argued by these scholars, not what is written in HRM policy documents, but how HRM practices are perceived by employees affects their attitudes, perceptions, and behavior (Den Hartog et al., 2013).

This article is structured as follows. First, we present a number of hypotheses based on a literature review of HPWPs, proactivity, and vitality. Next, we describe the method and results of the study. Finally, we discuss which HPWPs are important for stimulating employees to cope with (or to be ready for) organizational change. 


\section{Theoretical Framework}

\section{The importance of active employee outcomes for organizational change}

In line with the resource-based view of organizations (Barney, 1991), HRM scholars have investigated how HRM practices influence employee attitudes and behavior (Macky and Boxall, 2007). Moreover, HRM scholars have examined how these individual outcomes, in turn, have an impact on organizational outcomes (Huselid, 1995).

As noted, HRM researchers often focused on 'passive' employee outcomes, such as job satisfaction, organizational commitment and turnover. Being able to manage passive outcomes successfully is important as these outcomes can have important consequences for employees and their organization, including employee well-being, burnout risks, and staffing costs (Griffeth et al., 2000).

However, being successful in managing passive employee outcomes is not enough when confronted with organizational change. For example, employees can be very satisfied with their job, but simultaneously be extremely passive in their behavior (e.g., arriving at 10AM, taking an extensively long lunch break, unwilling to help colleagues). Such satisfied, but passive employees will, in all likelihood, not show much initiative to turn organizational changes into a success. Therefore, positive psychology argues that active employee outcomes should be considered if one wants to change successfully (Frese et al., 1997; Sonnentag and Frese, 2002).

Proactivity has two distinctive features (Grant and Ashford, 2008). First, to say that an employee shows proactive behaviour implies that the person is planning and acting to anticipate possible future events. Second, proactive behaviour is change oriented. A proactive employee intends to alter the self, co-workers, or the work context to adapt to the anticipated changing conditions. For example, proactive employees may anticipate design flaws in the 


\section{CONNECTING HRM AND CHANGE MANAGEMENT}

implementation process and develop creative fixes. Hence, higher levels of proactivity reduce unnecessary workload and facilitate organizational change.

A vital person approaches work with positive energy and excitement. Vital employees believe that their behavior contributes to a meaningful purpose (Ryan and Bernstein, 2004) . A vital person does not do "things halfway or halfheartedly" (Kark and Carmeli, 2009 p.789). As such, the degree of vitality affects the time and effort employees are willing to invest in particular activities. Jansen (2004) concluded that employees require a high amount of vitality to deal with organizational change, especially because changes often have to be implemented next to regular duties.

\section{Connecting HPWPs to proactivity and vitality}

Boselie et al. (2005) examined over a hundred articles that linked HRM practices to performance. Based on this review, they developed a list of 26 often-used HRM practices. From Boselie, et al.'s top ten list, we selected five HRM practices: 1) training and development, 2) feedback, 3) job autonomy, 4) participation in decision-making and 5) teamwork. These five HRM practices (or HPWPs) were chosen given that they a) were important HRM practices, b) were expected to influence proactivity and vitality, c) could be measured on the employee level; and d) had available well-validated measures (Judge et al., 1999; Tummers et al., 2012).

Before discussing the five HRM practices, we should acknowledge the discussion between studying individual HR practices (such as training) or HRM systems (in short, summing up HRM practices to create one overall score of an organization's HRM system). The systems approach is often used when analyzing the effects of intended or actual HRM practices on organizational performance (e.g., Delaney and Huselid, 1996). However, some 


\section{CONNECTING HRM AND CHANGE MANAGEMENT}

HRM scholars argue that we should focus on HRM practices instead of HRM systems when analyzing perceived HR practices (e.g., Veld et al., 2010).

The advantage of studying individual HRM practices is firstly methodological. Items are more specifically related to a specific HRM practice than to a broad HRM system. For instance, the item "I receive ongoing training which enables me to do my job better' is directly related to the practice of training, instead of to a more distant and general HRM system. This is valuable when analyzing what HR practices have the strongest relationship with outcome variables. Next to this, when specifically focusing on HRM practices, one can hypothesize potential interaction effects instead of assuming them to exist. In this study, we examine the individual impact of various HRM practices, but we fully acknowledge the merits of the systems approach. Next, the five HRM practices and their potential impact on proactivity and vitality will be discussed.

Training and development. It is expected that employees who experience training and development opportunities report higher levels of proactive behavior (Frese and Fray, 2001; Van Veldhoven and Dorenbosch, 2008). First, training opportunities may enhance employees' feeling of self-efficacy (Parker, 1998) defined as a someone's judgment of "how well one can execute courses of action required to deal with prospective situations" (Bandura, 1982, p. 122). By the same token, training possibilities may contribute to higher levels of control appraisal, defined as someone's feeling that one can actually influence work-related decisions (Frese and Fray, 2001). Lastly, training opportunities may stimulate feelings of responsibility for organizational success. Self-efficacy, control appraisal, and feelings of responsibility, in turn, result in proactive behavior (Frese and Fray, 2001).

In a similar vein, we expect that training and development opportunities stimulate employee vitality, since self-efficacy, control appraisal, and feelings of responsibility 


\section{CONNECTING HRM AND CHANGE MANAGEMENT}

contribute to positive thoughts about one's own capabilities to bring change about (Carmeli and Spreitzer, 2009, p. 169). Furthermore, training and development stimulate employees intellectually_giving "food for thought". Such intellectual stimuli have a positive impact on excitement and vitality (Kinjerski and Skrypnek, 2006).

H1a: Perceived training is positively related to proactivity.

H1b: Perceived training is positively related to vitality.

Feedback from supervisors and co-workers. Similar to perceived training opportunities, constructive feedback from supervisors and colleagues provides cues about how to increase self-efficacy, control appraisal, and stimulates feelings of responsibility (Crant, 2000). Moreover, Shraga and Shirom (2009) found that employees often mention factors related to feedback from supervisors when describing situations in which they experienced high levels of vitality. As expected by leadership-member exchange theory, respondents stated that they felt appreciated or acknowledged when receiving feedback from their supervisor regardless of the content of the message. By the same token, constructive feedback from colleagues may increase employees' feelings of appreciation and, thus, vitality (Kark and Carmeli, 2009; Kinjerski and Skrypnek, 2006). Hence, we expect that perceived work-related feedback from supervisors and co-workers enhances proactivity and vitality.

H2a: Perceived feedback is positively related to proactivity.

$\mathrm{H} 2 \mathrm{~b}$ : Perceived feedback is positively related to vitality.

Job autonomy. We expect that higher levels of perceived job autonomy are positively related to proactivity. If employees have influence over a broad range of work-related decisions, they develop enhanced level of control appraisal and a feeling of responsibility (Fuller et al., 2007). 


\section{CONNECTING HRM AND CHANGE MANAGEMENT}

Furthermore, we expect perceived job autonomy to be positively related to vitality (Shirom, 2011). Building upon self-determination theory (Deci and Ryan, 2000), scholars showed that autonomy is a basic human need that stimulates feelings of vitality. Ryan and Frederick (1997) found, for example, that respondents reported higher levels of vitality when they completed autonomously motivated actions. In contrast, respondents reported lower levels of vitality when they perceived themselves as controlled by external forces.

H3a: Perceived autonomy is positively related to proactivity.

H3b: Perceived autonomy is positively related to vitality.

Participation in decision-making. Similar to the aforementioned HRM practices, higher levels of perceived participation in decision-making results in higher levels of control appraisal and feelings of responsibility (Jackson, 1983; Shirom, 2011). Moreover, being involved in workrelated decisions enhances feelings of self-efficacy. Participation in decision-making implies, for example, that employees have a voice in setting performance goals and are involved in evaluating their own achievements. Such possibilities stimulate feelings of shared responsibility and personal initiative (Kirkman and Rosen, 1999). Moreover, feeling able to have a voice in decision-making processes stimulates employees to invest more energy in their work (Hülsheger et al., 2009).

Related to this, scholars in the field of workplace creativity stress the importance of establishing an open and safe work climate (Edmondson, 2004). Stimulating employees to participate in decision-making processes plays an important role in establishing a psychological safe climate. In such a climate people believe that they can safely express their own opinion and, thus, are likely to proactively come up with ideas to deal with work-related problems (Baer and Frese, 2003).

H4a: Perceived participation in decision-making is positively related to proactivity. 


\section{CONNECTING HRM AND CHANGE MANAGEMENT}

H4b: Perceived participation in decision-making is positively related to vitality.

Teamwork. Lastly, teamwork may also increase both employee involvement and perceived level of self-control (Frese and Fay, 2001), and thus we predict that higher levels of perceived team working enhances job proactivity. Furthermore, being part of a team may increase feelings of a sense of belonging (Van Mierlo et al., 2001). These feelings, in turn, stimulate feeling of shared responsibility and higher levels of vitality to engage in group-related activities (Bollen and Hoyle, 1990).

H5a: Perceived teamwork is positively related to proactivity.

H5b: Perceived teamwork is positively related to vitality.

Relationship between proactivity and vitality. Lastly, we expect proactivity and vitality to be positively related. Specifically, we hypothesize that proactive employees feel energized by observing the positive outcomes of their proactive behavior (Shirom, 2011). Simultaneously, we expect that employees who experience higher levels of vitality are more likely to take action themselves to improve their work conditions or adjust to changing circumstances (Salanova and Schaufeli, 2008).

H6: Proactivity and vitality are positively related.

\section{Research model}

Figure 1 shows the research model representing the research hypotheses. In the next sections, we present the methodology used to test this model and our empirical results. 


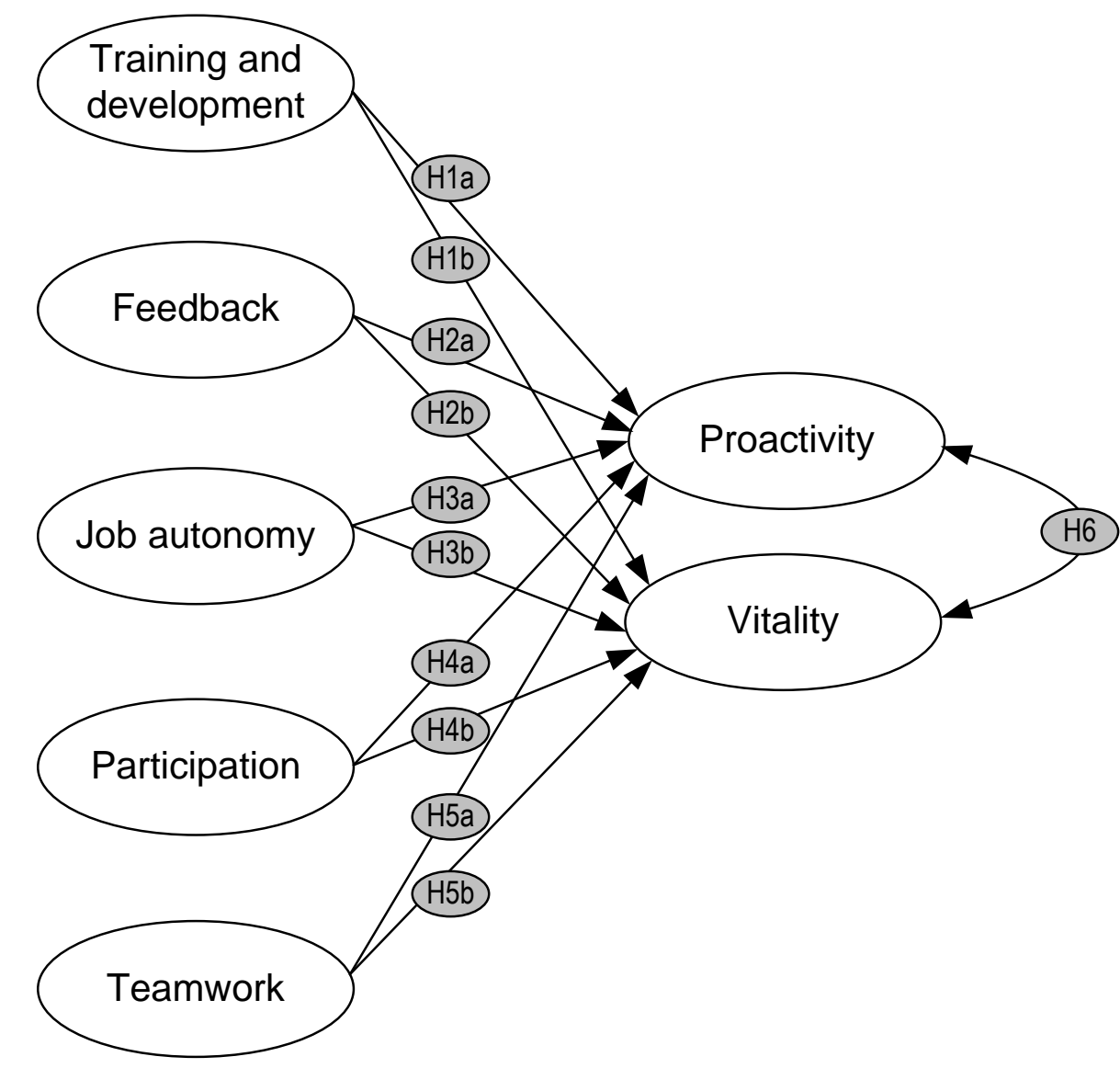

Figure 1: Hypothesized effects of HPWPs on active employee-outcomes.

\section{Method}

\section{Procedure and participants}

Data were collected between 2010 and 2011 in three large public healthcare organizations in the Netherlands using an anonymous electronic survey (developed by Stichting IZZ, supported by $\mathrm{PwC}$ ). The Dutch public healthcare sector is an important subsector to study, as it has been confronted with major policy shifts and related organizational changes due to expanding costs, the felt need to increase transparency, and a wish to stimulate client choice (Tummers and Van de Walle, 2012; Helderman et al., 2005).

The electronic survey was emailed to all 2,876 employees of the participating organizations. After an introductory email and various reminders, 1,507 employees responded 


\section{CONNECTING HRM AND CHANGE MANAGEMENT}

( $52 \%$ response rate). $91 \%$ were female, which is comparable to the Dutch healthcare sector (91\%, see Vernet, 2010). Respondents' mean age was 42, which is also similar to the mean age of Dutch healthcare workers.

Of all respondents, $9 \%$ had a managerial position. Many employees followed intermediate vocational education (59\%, in Dutch: MBO) or higher vocational education (22\%, in Dutch HBO). Most respondents worked as caretakers or nurses (67\%), in facility management (10\%), or were administrative staff $(4 \%)$.

\section{Structural equation modeling}

We tested the research model as specified in Figure 1 using SEM. SEM has several advantages over exploratory factor analysis and regression analyses_-including more stringent psychometric criteria for testing model fit - thereby improving validity and reliability. However, given that CFA is often more stringent than standard Cronbach alpha reliability measures, we removed several items to maintain adequate model fit (Kline, 2010).

To deal with the potential validity problem caused by the removal of scale items, we pursued two strategies. First, we checked inter-item correlations and reliability coefficients, but did not find important differences between scales with and without deleted items. Second, we reviewed the content of all items and found that all constructs are still fully represented by the preserved items.

\section{Measures}

All items were scored on a five-point scale ranging from 1 ("strongly disagree") to 5 ("strongly agree"). Scale reliabilities — as estimated by coefficient alpha—were highly adequate, ranging from .79 (teamwork) to .90 (training and development).

Training and development. We used Vandenberg et al.'s (1999) five-item training scale to tap perceived training and development opportunities. A sample item was "I receive ongoing training which enables me to do my job better". 


\section{CONNECTING HRM AND CHANGE MANAGEMENT}

Feedback from supervisors and co-workers. We analyzed perceived feedback by Wright's (2004) four-item scale. A sample item was "My last performance evaluation assisted me in improving my work." We removed the item "I receive useful evaluations of my strengths and weaknesses at work" to improve model fit.

Job autonomy. To measure job autonomy, we used the five-item scale developed by Reychav and Sharkie (2010). A sample item is "I have freedom to adopt my own approach to the job". The item "I have control over how quickly or slowly I work" was removed to improve model fit.

Participation in decision-making. We used Reychav and Sharkie's (2010) five-item scale to tap participation in decision-making. A sample item was "I am able to influence the decisions made in my organization". We removed the item "I am given an opportunity to express my views before my supervisor makes a decision" to improve model fit.

Teamwork. Teamwork was tapped using the three-item scale developed by Campion and Medsker (1993). A sample item was "Members of my team are very willing to share information with other team members about our work". The item "Members of my team cooperate to get the work done" was removed to improve model fit.

Proactive behavior. Proactive behavior was measured using the seven-item selfinitiative scale developed by Frese et al., (1997). A sample item was "Whenever there is a chance to be actively involved, I take it".

Vitality. In order to measure vitality, we used the five-item scale developed by Kark and Carmeli (2009) A sample item was "I am full of positive energy when I am at work".

Control variables. We included the following control variables in our model: gender (male, female), age (ten categories, ranging from 25 years or younger, 26-30 years... to 61-65 years, and 66 years or older), highest obtained educational degree (seven categories, ranging from primary school to post academic), organizational unit, and two organizational dummies. 


\section{CONNECTING HRM AND CHANGE MANAGEMENT}

\section{Statistical analyses}

SEM analyses were carried out in Mplus. Correlated-error terms were not used given the recommendations of Hooper et al. (2008). Hypotheses were tested using standardized coefficients obtained by means of maximum likelihood estimation. To assess model fit, we used standard factor loadings (>.30), CFI (>.90), TLI (>.90), and RMSEA (<. 08) (Hair et al., 1998). Because of the large sample size, we decided to test the hypotheses at the $1 \%$ significance level.

We computed the interclass correlation coefficient (ICC) to investigate if employees' degree of proactivity and vitality varied substantially across organizational units. ICC-values as small as .05 indicate that a multilevel effect should be included in the SEM model (Hayes, 2006). As we found ICC values $<.04$ - which implies that at most $4 \%$ of the variance in both dependent variables could be explained by differences in organizational unit membershipwe decided not to proceed with a multilevel model.

\section{Results}

The measurement model provided a good fit to the data (CFI=.94, TLI=.93, RMSEA=.04). Based on the measurement model, a structural model was constructed relating the five HPWPs to proactivity and vitality. This model also proved to fit the data quite well (CFI=.92; TLI=.91; RMSEA=.05) with adequate explained variances of $.13(\mathrm{p}<.01)$ for proactivity and $.25(\mathrm{p}<.01)$ for vitality. Moreover, the analyses confirmed the existence of a factor structure with standardized factor loadings ranging from .43 to .87 . Figure 2 shows the final model with significant standardized path coefficients $\beta(\mathrm{p}<.01)$ only. 


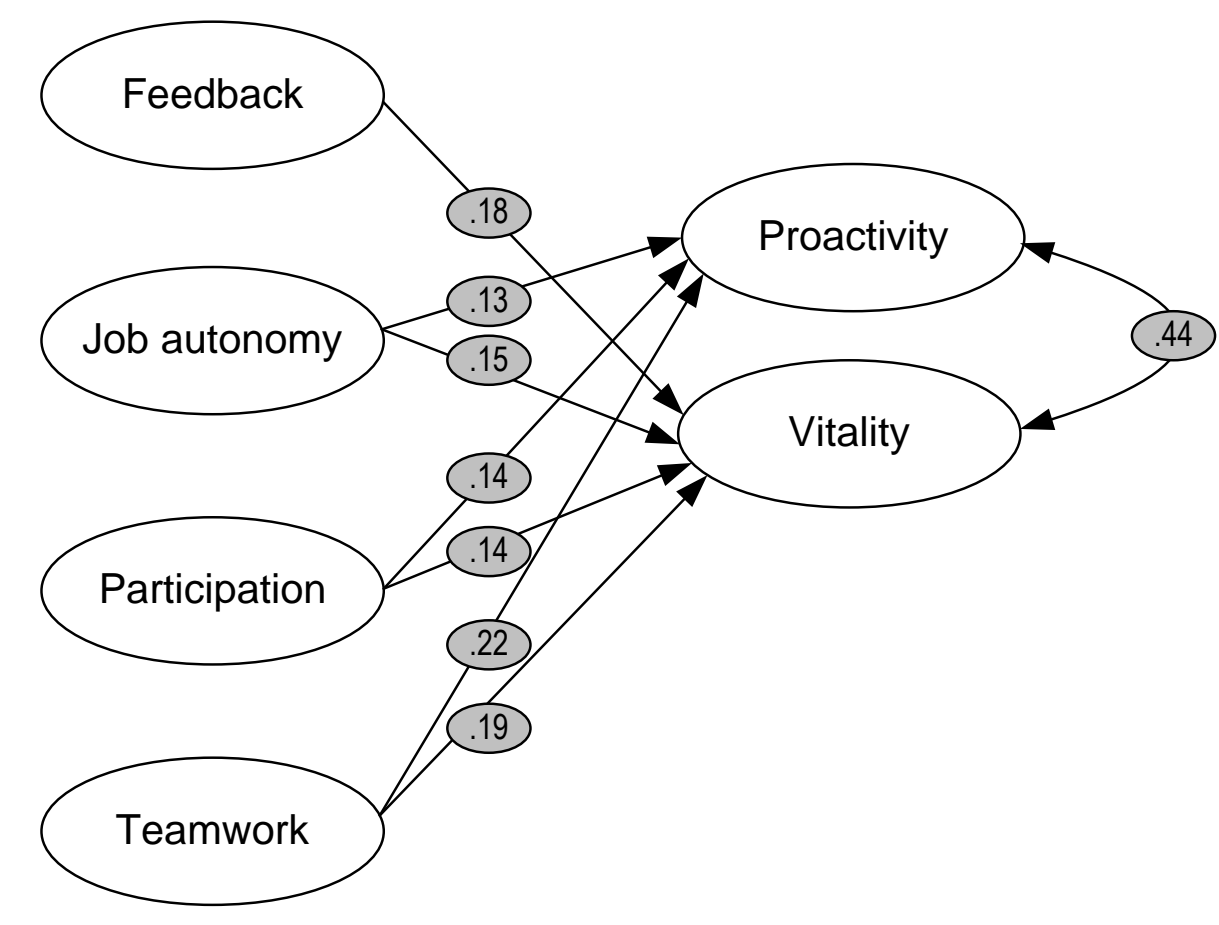

Figure 2: Effects of HPWPs on active employee-outcomes with significant standardized path coefficients $\beta(p<.01)$.

Interestingly, 'only' three of the five studied HPWPs showed a positive relationship with both proactivity and vitality. Specifically, increased levels of perceived autonomy, participation in decision-making, and teamwork were related to higher levels of proactivity and vitality (i.e., H3a, H3b, H4a, H4b, H5a, and H5b). Standardized path coefficients of these HPWPs varied from .14 to .22 , with an average of .16. Moreover, the results showed that our last hypothesis (H6) was accepted as well. That is, proactivity and vitality were positively related (correlation $=.44)$.

In contrast, the first two hypotheses ( $\mathrm{H} 1 \mathrm{a}$ and $\mathrm{H} 1 \mathrm{~b})$ had to be rejected. We found no significant relationship between perceived level of training and development on the one hand and degree of proactivity and vitality on the other hand. Also our third hypothesis (H2a) had to be rejected. The data showed no relationship between perceived feedback and level of proactivity. 


\section{CONNECTING HRM AND CHANGE MANAGEMENT}

The control variables (results not shown due to space limitations) showed no significant relationship with proactive behavior. With respect to effects of the control variables on employee vitality, the results showed that vitality did not differ between male and female employees. However, older employees were generally more vital $(\beta=.07)$, the level of vitality decreased with education $(\beta=-.11)$, and the average degree of vitality was around .10 standard deviations lower for employees of two participating organizations compared to the third organization.

\section{Discussion}

Organizations, in the private sector but also increasingly in the public sector, are faced with rapidly changing conditions including budget cuts, altered client demands, and changing demographics (By and Macleod, 2009; Kuipers et al., 2014). In order to cope with those changing conditions, organizations require their employees to be ready for organizational change. This study was innovative in two ways. First, we focused on the effects of HPWPs on active employee-outcomes in order to enhance readiness for organizational change, thereby connecting HRM with change management. Second, we analyzed perceived HPWPs instead of intended or actual HRM practices given that perceived HPWPs are often directly linked to performance.

Our research showed that 1) job autonomy; 2) participation in decision-making, and 3) teamwork were positively related to proactivity and vitality, and hence likely facilitate employees to cope better with organizational change. In contrast, training and development as well as perceived feedback seemed unrelated to proactivity. Even if employees perceive sufficient training and constructive feedback, signals sent during training and feedback may (un)intentionally result in passive behavior. Hence, if one wants to enhance proactivity by means of training and feedback, one should think carefully about employees' interpretations 


\section{CONNECTING HRM AND CHANGE MANAGEMENT}

of the messages conveyed. We found, moreover, no effects of perceived training and development on vitality. Likely, some employees may experience training as too demanding or too time-consuming (Fransman, 2014). Consequently, positive and negative effects of training on vitality may cancel each other out.

Interestingly, the studied HPWPs are aimed at increasing employees' self-control, which proves a challenge to managers who try to implement organizational changes top down, given that top-down implementation implies a reduced level of employees' selfcontrol. Related studies also show that increasing autonomy can be beneficial for organizational change. For example, Tummers (2011) showed that when healthcare professionals experienced more autonomy during the implementation of a policy, they were significantly less resistant towards the policy. Moreover, Armenakis et al. (1993) showed that readiness for change is enhanced by showing management support for the proposed change, and when management clearly communicates the content of the proposed change. Our research suggest that readiness for change can also be achieved by approaching employees more actively by means of HR instruments.

We acknowledge that positive employee-characteristics as well as organizational change itself does not guarantee positive outcomes. Proactive employees may get demotivated by stubborn colleagues or think an organization is not moving fast enough. Vital employees may put all their energy in sabotaging unwelcome change. Hence, although we - and other scholars (Frese and Fay, 2001, Ghitulescu, 2013) - expect a positive relationship between proactivity and vitality on the one hand and successful organizational change on the other, this is not necessarily the case. Scholars could research the 'dark side' of employee proactivity and vitality.

This study ends with some limitations. The quantitative survey-approach of this study was strengthened by using a large sample, validated scales, and sophisticated analysis 


\section{CONNECTING HRM AND CHANGE MANAGEMENT}

techniques. Nevertheless, cross-sectional studies cannot explicitly examine process-related factors. A fruitful direction for future research would therefore be to carry out a longitudinal multi-method study. Longitudinal studies are expensive and complex to manage, but they do have the potential to provide fresh insights into important phenomena, such as how HRM practices can enhance organizational change.

Concluding, our empirical results emphasize the importance of HPWPs. In line with Boxall and Purcell (2000), we note that "HRM matters" (see also Rodwell and Teo, 2008). Our research findings more specifically note that three HR practices are particularly effective for improving proactivity and vitality, which are often related to effective organizational change: 1) autonomy, 2) participation in decision-making, and 3) teamwork. 


\section{References}

Armenakis, A.A., Harris, S.G. and Mossholder, K.W. (1993), "Creating readiness for organizational change”, Human Relations, Vol. 46, No. 6, pp. 681-703.

Baer, M. and Frese, M. (2003), "Innovation is not enough: Climates for initiative and psychological safety, process innovations, and firm performance”, Journal of Organizational Behavior, Vol. 24, No. 1, pp. 45-68.

Bandura, A. (1982), "Self-efficacy mechanism in human agency", American Psychologist, Vol. 37, No. 2, pp. 122-147.

Barney, J. (1991), "Firm resources and sustained competitive advantage", Journal of Management, Vol. 17, No. 1, pp. 99-120.

Bauer, T.K. (2004), High Performance Workplace Practices and Job Satisfaction: Evidence from Europe, Institute for the Study of Labor, Bonn, Germany.

Bollen, K.A. and Hoyle, R.H. (1990), "Perceived cohesion: A conceptual and empirical examination”, Social Forces, Vol. 69, No. 2, pp. 479-504.

Boselie, P., Dietz, G. and Boon, C. (2005), “Commonalities and contradictions in HRM and performance research”, Human Resource Management Journal, Vol. 15, No. 3, pp. 6794.

Boxall, P. and Purcell, J. (2000), "Strategic human resource management: Where have we come from and where should we be going?", International Journal of Management Reviews, Vol. 2, No. 2, pp. 183-203.

By, R.T. and Macleod, C. (Eds.) (2009), Managing Organizational Change in Public Services: International Issues, Challenges and Cases, Routledge, London, United Kingdom. 


\section{CONNECTING HRM AND CHANGE MANAGEMENT}

Campion, M.A. and Medsker, G.J. (1993), "Relations between work group characteristics and effectiveness: Implications for designing effective work groups", Personnel Psychology, Vol. 46, No. 4, pp. 823-847.

Carmeli, A. and Spreitzer, G.M. (2009), “Trust, connectivity, and thriving: Implications for innovative behaviors at work", The Journal of Creative Behavior, Vol. 43, No. 3, pp. 169-191.

Combs, J. Liu, J. Hall, A. and Ketchen, D. (2006), "How much do High Performance Work Practices matter? A meta-analysis of their effects on organizational performance", Personnel Psychology, Vol. 59, No. 3, pp.501-528.

Crant, J.M. (2000), "Proactive behavior in organizations", Journal of Management, Vol. 26, No. 3, pp. 435-462.

Deci, E.L. and Ryan, R.M. (2000), “The what and why of goal pursuits: Human needs and the self-determination of behavior”, Psychological Inquiry, Vol. 11, No.4, pp. 227-268.

Delaney, J.T. and Huselid, M.A. (1996), “The impact of human resource management practices on perceptions of organizational performance", Academy of Management Journal, Vol. 39, No. 4, pp. 949-969.

Den Hartog, D.N., Boon, C., Verburg, R.M. and Croon, M.A. (2013), "HRM, communication, satisfaction, and perceived performance: A cross-level test", Journal of Management, Vol. 39, No. 6, pp. 1637-1665.

Doorewaard, H. and Benschop, Y. (2003), “HRM and organizational change: An emotional endeavor", Journal of Organizational Change Management, Vol. 16, No. 3, pp. 272 286.

Edmondson, A.C. (2004), "Psychological safety, trust, and learning in organizations: A group-level lens”, in Kramer, R.M. and Cook K.S. (Eds.), Trust and Distrust in 


\section{CONNECTING HRM AND CHANGE MANAGEMENT}

Organizations: Dilemmas and Approaches, Russell Sage Foundation, New York, NY, pp. 239-272.

Fransman, N. (2014), “The impact of High Performance Work Systems on nurses" ["Invloed van High Performance Work Systems op werkstress bij verplegend personeel in de zorg"], MA Dissertation, Radboud University Nijmegen, the Netherlands.

Frese, M. and Fay, D. (2001), "Personal initiative: An active performance concept for work in the 21st century", Research in Organizational Behavior, Vol. 23, No. NA, pp. 133-187.

Frese, M., Fay, D., Hilburger, T., Leng, K. and Tag, A. (1997), "The concept of personal initiative: Operationalization, reliability and validity in two German samples", Journal of Occupational and Organizational Psychology, Vol. 70, No. 2, pp. 139-161

Fuller, J.B., Marler, L.E. and Hester, K. (2006), "Promoting felt responsibility for constructive change and proactive behavior: Exploring aspects of an elaborated model of work design”, Journal of Organizational Behavior, Vol. 27, No. 8, pp. 1089-1120.

Ghitulescu, B.E. (2013), "Making change happen: The impact of work context on adaptive and proactive behaviors", The Journal of Applied Behavioral Science, Vol. 49, No. 2, pp. 206-245.

Grant, A.M. and Ashford, S.J. (2008), "The dynamics of proactivity at work", Research in Organizational Behavior, Vol. 28, No. NA, pp. 3-34.

Griffeth, R.W., Hom, P.W. and Gaertner, S. (2000), “A meta-analysis of antecedents and correlates of employee turnover: Update, moderator tests, and research implications for the next millennium", Journal of Management, Vol. 26, No. 3, pp. 463-488.

Hair, J.F., Black, W.C., Babin, B.J., Anderson, R.E. and Tatham, R.L. (1998), Multivariate Data Analysis, Prentice Hall, London, United Kingdom.

Hayes, A.F. (2006), “A primer on multilevel modeling”, Human Communication Research, Vol. 32, No. 4, pp. 385-410. 


\section{CONNECTING HRM AND CHANGE MANAGEMENT}

Helderman, J.K., Schut, F.T., Van der Grinten, T.E. and Van de Ven, W.P. (2005), "Marketoriented health care reforms and policy learning in the Netherlands", Journal of Health Politics, Policy and Law, Vol. 30, No. 1-2, pp. 189-210.

Hooper, D., Coughlan, J. and Mullen, M. (2008), “Structural equation modelling: Guidelines for determining model fit", Electronic Journal of Business Research Methods, Vol. 6, No. 1, pp. 53-60.

Hornung, S. and Rousseau, D.M. (2007), “Active on the job-Proactive in change: How autonomy at work contributes to employee support for organizational change", The Journal of Applied Behavioral Science, Vol. 43, No. 4, pp. 401-426.

Hülsheger, U.R., Anderson, N. and Salgado, J.F. (2009), “Team-level predictors of innovation at work: A comprehensive meta-analysis spanning three decades of research", Journal of Applied psychology, Vol. 94, No. 5, pp. 1128-1145.

Huselid, M.A. (1995), “The impact of human resource management practices on turnover, productivity, and corporate financial performance", Academy of Management Journal, Vol. 38, No. 3, pp. 635-672.

Jackson, S.E. (1983), "Participation in decision making as a strategy for reducing job-related strain”, Journal of Applied Psychology, Vol. 68, No. 1, pp. 3-19.

Jansen, K.J. (2004), "From persistence to pursuit: A longitudinal examination of momentum during the early stages of strategic change”, Organization Science, Vol. 15, No. 3, pp. 276-294.

Josserand, E., Teo, S. and Clegg, S. (2006), "From bureaucratic to post-bureaucratic: The difficulties of transition”, Journal of Organizational Change Management, Vol. 19, No. 1, pp. 54-64. 


\section{CONNECTING HRM AND CHANGE MANAGEMENT}

Judge, T.A., Thoresen, C.J., Pucik, V. and Welbourne, T. M. (1999), "Managerial coping with organizational change: A dispositional perspective", Journal of Applied Psychology, Vol. 84, No. 1, pp. 107-122.

Kark, R. and Carmeli, A. (2009), "Alive and creating: the mediating role of vitality and aliveness in the relationship between psychological safety and creative work involvement", Journal of Organizational Behavior, Vol. 30, No. 6, pp. 785-804.

Kinjerski, V. and Skrypnek, B.J. (2006), "Creating organizational conditions that foster employee spirit at work", Leadership \& Organization Development Journal, Vol. 27, No. 4, pp. 280-295.

Kirkman, B.L. and Rosen, B. (1999), "Beyond self-management: Antecedents and consequences of team empowerment", Academy of Management Journal, Vol. 42, No. 1, pp. 58-74.

Kline, R.B. (2010), Principles and Practice of Structural Equation Modeling, The Guilford Press, London, United Kingdom.

Kuipers, B.S., Higgs, M.J., Kickert, W.J.M., Tummers, L.G., Grandia, J., and Van der Voet, J. (2014), "The management of change in public organizations: A literature review", Public Administration, Vol. 20, No. 1, pp. 1-20.

Macky, K. and Boxall, P. (2007), “The relationship between 'High-Performance Work Practices' and employee attitudes: An investigation of additive and interaction effects", International Journal of Human Resource Management, Vol. 18, No. 4, pp. 537 -567.

Parker, S.K. (1998), "Enhancing role breadth self-efficacy: The roles of job enrichment and other organizational interventions", Journal of Applied Psychology, Vol. 83, No. 6, pp. 835-852.

Reychav, I. and Sharkie, R. (2010), “Trust: An antecedent to employee extra-role behavior”, Journal of Intellectual Capital, Vol. 11, No. 2, pp. 227-247. 


\section{CONNECTING HRM AND CHANGE MANAGEMENT}

Rodwell, J.J. and Teo, S.T. (2008), “The influence of strategic HRM and sector on perceived performance in health services organizations", The International Journal of Human Resource Management, Vol. 19, No. 10, pp. 1825-1841.

Rush, M.C., Schoel, W.A. and Barnard, S.M. (1995), "Psychological resiliency in the public sector: 'Hardiness' and pressure for change”, Journal of Vocational Behavior, Vol. 46, No. 1, pp. 17-39.

Ryan, R.M. and Bernstein, J.H. (2004). "Vitality", in Peterson, C. and Seligman, M.E.P. (Eds.), Character Strengths and Virtues: A Handbook and Classification, Oxford University Press, New York, NY, pp. 273-290.

Ryan, R.M. and Frederick, C. (1997), “On energy, personality, and health: Subjective vitality as a dynamic reflection of well-being”, Journal of Personality, Vol. 65, No. 3, pp. 529565.

Salanova, M. and Schaufeli, W.B. (2008), "Job resources, engagement and proactive behavior”, International Journal of Human Resource Management, Vol. 19, No. 1, pp. $116-131$.

Shirom, A. (2011), "Vigor as a positive affect at work: Conceptualizing vigor, its relations with related constructs and its antecedents and consequences", Review of General Psychology, Vol. 15, No. 1, pp. 50-64.

Shraga, O. and Shirom, A. (2009), "The construct validity of vigor and its antecedents: A qualitative study", Human Relations, Vol. 62, No. 2, pp. 271-291.

Sonnentag, S. and Frese, M. (2002), "Performance concepts and performance theory: Psychological management of individual performance”, in Sonnentag, S. (Ed.), Psychological Management of Individual Performance, Wiley, London, United Kingdom, pp. 3-25. 


\section{CONNECTING HRM AND CHANGE MANAGEMENT}

Tummers, L.G. (2011), "Explaining the willingness of public professionals to implement new policies: A policy alienation framework", International Review of Administrative Sciences, Vol. 77, No. 3, pp. 555-581.

Tummers, L.G., Steijn, A.J. and Bekkers, V.J.J.M. (2012), “Explaining the willingness of public professionals to implement public policies: Content, context, and personality characteristics, Public Administration, Vol. 90, No. 3, pp. 716-736.

Tummers, L.G. and Van de Walle, S. (2012), 'Explaining health care professionals' resistance to implement Diagnosis Related Groups: (No) benefits for society, patients and professionals", Health Policy, Vol. 108, No. 2, pp. 158-166.

Tushman, M.L. and O’Reilly, C.A. (2013), Winning Through Innovation: A Practical Guide to Leading Organizational Change and Renewal, Harvard Business Press, Boston, MA.

Vakola, M. and Nikolaou, I. (2005), “Attitudes towards organizational change: What is the role of employees' stress and commitment?”, Employee Relations, Vol. 27, No. 2, pp. $160-174$.

Vandenberg, R.J., Richardson, H.A. and Eastman, L.J. (1999), “The impact of high involvement work processes on organizational effectiveness a second-order latent variable approach”, Group \& Organization Management, Vol. 24, No. 3, pp. 300-339.

Van der Voet, J., Groeneveld, S.M. and Kuipers, B.S. (2013), "Talking the talk or walking the walk? The leadership of planned and emergent change in a public organization, Journal of Change Management, Vol. 14, No. 2, pp. 171-191.

Van Mierlo, H., Rutte, C. G., Seinen, B. and Kompier, M. (2001), “Autonomous teamwork and psychological well-being", European Journal of Work and Organizational Psychology, Vol. 10, No. 3, pp. 291-301.

Van Veldhoven, M. and Dorenbosch, L. (2008), “Age, proactivity and career development", Career Development International, Vol. 13, No. 2, pp. 112-131. 


\section{CONNECTING HRM AND CHANGE MANAGEMENT}

Veld, M., Paauwe, J. and Boselie, P. (2010), "HRM and strategic climates in hospitals: Does the message come across at the ward level?", Human Resource Management Journal, Vol. 20, No. 4, pp. 339-356.

Vernet, (2010) VERNET Verzuimregistratie. See http://www.vernet.nl/

Wright, B.E. (2004), "The role of work context in work motivation: A public sector application of goal and social cognitive theories", Journal of Public Administration Research and Theory, Vol. 14, No. 1, pp. 59-78.

Wright, P.M., Gardner, T.M., Moynihan, L.M. and Allen, M.R. (2005), “The relationship between HRM practices and firm performance: Examining causal order”, Personnel Psychology, Vol. 58, No. 2, pp. 409-446. 